\title{
Evaluation The Success Restoration of Mangrove Ecosystem In South Malang Ecotourims Area Using Macroinvertebrates As Bioindicator
}

\author{
Ayu Maharani Siswandari*, Catur Retnaningdyah ${ }^{* *}$, Luchman Hakim $^{* *}$ \\ * Magister Program of Biology, Faculty of Mathematics and Natural Sciences, University of Brawijaya, Malang, East Java, Indonesia \\ ** Department of Biology, Faculty of Mathematics and Natural Sciences, University of Brawijaya, Malang, East Java, Indonesia
}

DOI: 10.29322/IJSRP.10.07.2020.p10362

http://dx.doi.org/10.29322/IJSRP.10.07.2020.p10362

\begin{abstract}
The potential of an ecotourism location can be analyzed based on evaluating the success of the restoration program using several indicators, one of which is macroinvertebrates diversity. This research was conducted in Bajulmati Beach, Clungup Mangrove Conservation (CMC) Beach, and Kondang Iwak Beach with 3 different lengths of restoration (except Kondang Iwak as a reference site). The measured data include physicochemical parameter, mangrove vegetation profiles, and macroinvertebrate profiles. Furthermore, it is used as a basis for the formulation of a restoration recommendation strategy. The results of the study showed that the presentation of land cover in Bajulmati and Kondang Iwak were classified as rare $(<5 \%)$, while CMC was classified as tight (between $5-25 \%$ ). Macroinvertebrates were found in a total of 20 species of gastropods and 9 species of crabs. It shows that the macroinvertebrates had a special tendencies in certain habitats.
\end{abstract}

Index Terms- Ecotourism, Macroinvertebrates, Mangrove Restoration

\section{INTRODUCTION}

$\mathrm{M}$ angrove is one of the important ecosystem in coastal area

between land and sea environments, affected by tides in the tropics and subtropics [1]. Mangrove has crucial roles, including balancing environmental quality and neutralizing pollutants. Mangroves also provide food (both in the form of plants and animals that can be consumed by humans), medicines, fuels, and building materials and increase the value of biodiversity for the local community.

Humans contribute to mangrove degradation by carrying out various activities around mangrove conservation areas such as the conversion of conservation land to settlements, ports, ponds, tourist sites and other means of life. Most of these activities do not pay attention to aspects of environmental sustainability, causing biodiversity loss due to increased coastal community activities [2]. Mangrove forests which were continually eroded by human activities will have an impact on the availability of habitats for various species of animals that inhabit the ecosystem. It also causes a decrease in the ability of ecosystems to neutralize pollutants, so that the level of ecosystem vulnerability becomes disturbed.

Based on data from the Dinas Kelautan dan Perikanan of Malang Regency in 2016, mangrove forests on the coast of Malang Regency covered an area of 343.5 hectares (ha) with a damage level of 161.1 ha. The mangrove rehabilitation program itself on average each year is only for an area of 5-10 ha. Therefore, various organizations ranging from formal institutions to local non-governmental organizations make some efforts to overcome the degradation of mangrove ecosystems. These efforts include replanting mangroves (reforestation) as a form of ecosystem restoration.

Restoration based on its function is one the strategy to rehabilitate and restore degraded ecosystems and promote the restoration of threatened species, their reintroduction into their natural habitat under suitable conditions [3]. The restoration program has been carried out on several beaches in South Malang, including Clungup Beach, Bajulmati Beach and Kondang Merak Beach. Based on interviews with managers, it is known that the Bajulmati and Clungup Mangrove Conservation areas have been carried out restoration programs almost every year. It is a program that was launched in every ecotourism activity. Kondang Iwak beach is one of the unspoiled beaches in the South Malang, so the mangrove ecosystem is still considered natural (have not been rehabilitated before).

Ecotourism is one of the approach to support environmental program, including restoration. According to Zambrano [4], ecotourism is an activity that usually used to study biodiversity, conservation, and ecology. Ecotourism was one of the ideal strategies to achieved a management balance between ecology and economy in the area. Some examples of research on restorationbased ecotourism in Indonesia are on the Pramuka Island of the Seribu Island National Park which has a Tourism Suitability Index (IKW) of 73.68\% in 2016 [5]. Whereas in Malang Regency based on Harahab's [6] research, it has IKW of $84.95 \%$ for mangrove ecotourism which are included in the appropriate category.

The success of restoration can be evaluated from numerous aspect. One of the aspect to evaluate restoration program is evaluate the availability of Ecosystem Services (ES), especially as a habitat for various fauna that inhabits mangrove ecosystems. Mangrove ecosystems provide provisioning services that are very important for environmental sustainability and community welfare in the form of the presence of several animals that can be 
utilized by humans such as fish, crabs, and shellfish, and mangrove trees trunks producing wood production [7].

The research objective was to evaluate the success of the restoration program and providing recommendations for the management of mangrove sustainable ecotourism in South Malang.

\section{METHODOLOGY}

\section{A. Study Area}

The research was conducted in two mangrove conservations in South Malang. The locations were Bajulmati Beach and Clungup Mangrove Conservation (CMC), and Kondang Iwak Beach (as reference site). Each location was divided into 3 stations, (except Kondang Iwak) where each station represents the years of the restoration. Station 1 Bajulmati was 5 years, station 2 in 7 years and station 3 in 10 years, while in CMC station 1 was 6 years, station 2 in 7 years, and 15 years in station 3 . Kondang Iwak consisted of 1 station that represented the natural state (reference site) of the mangrove ecosystem in South Malang. Each station has three line transects, with two plots each transect. The total plot is 42 units.

\section{B. Data Collection}

Data collection was carried out in November 2019 until January 2020, while data analysis was carried out in February to April 2020 in the Laboratory of Ecology and Biodiversity University of Brawijaya, Malang. Measurement of environmental parameters was done in-situ which was carried out directly on-site and ex-situ analyzed in the laboratory. Parameters that can be measured directly on site were water temperature and $\mathrm{pH}$. While salinity, turbidity, BOD, nitrate, orthophosphate, and DO were analyzed at the Animal Ecology and Diversity Laboratory, University of Brawijaya Malang.

Fauna data covering all types of macroinvertebrates from gastropods and crabs species associated with the mangrove were recorded based on the number of individuals and species obtained in the plot. Observation of macroinvertebrates was carried out using a plot measuring 1 x 1 meter. The identification of gastropods using "Catalogue of Marine Molluscs" by Anirudha Dey, while crabs identification using "Kepiting Uca di Hutan Mangrove Indonesia" by LIPI. The results of aquatic fauna data which were processed to get an abundance of fauna using the unit ind $/ \mathrm{m}^{2}$

The procedure for collecting vegetation data was counting the number of individuals (trees with $10 \times 10 \mathrm{~m}$ of plots, saplings in 5 x $5 \mathrm{~m}$, and seedlings in $2 \times 2 \mathrm{~m}$ ) of mangroves contained in a multilevel plot using a visual counting method [8]. As or the category of trees namely woody plants with a diameter of $>10 \mathrm{~cm}$, while for the size of saplings $\leq 10 \mathrm{~cm}$ and for seedlings have a height of $\leq 1 \mathrm{~m}$. The abundance parameters of each species were scored with a cover scale and tree abundance with reference to the Braun-Blanquet (BB) scale [9].

\section{RESULT AND DISCUSSION}

\section{A. Analysis of Mangrove Vegetation}

Stations 2 and 3 at Bajulmati were located in the western watershed of the Bajulmati river estuary and were closed to residential areas so that the mangrove area was very vulnerable to direct impacts from human activities. Both of the stations were dominated by mangrove trees with a total abundance of 10.3 and $10.17 \mathrm{Ind} / \mathrm{m}^{2}$ respectively. While station 1 was the Bajulmati river estuary which was directly adjacent to Ungapan Beach. This area was a fishing boat base and there were shrimp ponds and sugar cane plantations around it. Station 1 has the highest total seedling abundance than saplings and trees at $4.3 \mathrm{Ind} / \mathrm{m}^{2}$. Station 1 and 2 in $\mathrm{CMC}$ is an area that flooded adjacent to tourist areas and streams towards the estuary. Both stations have the highest total abundance in the seedling category, which is 29.7 and $32,5 \mathrm{Ind} / \mathrm{m}^{2}$, respectively. Whereas at station 3 it was dominated by mangrove trees at $22.17 \mathrm{Ind} / \mathrm{m}^{2}$ (fig. 1).

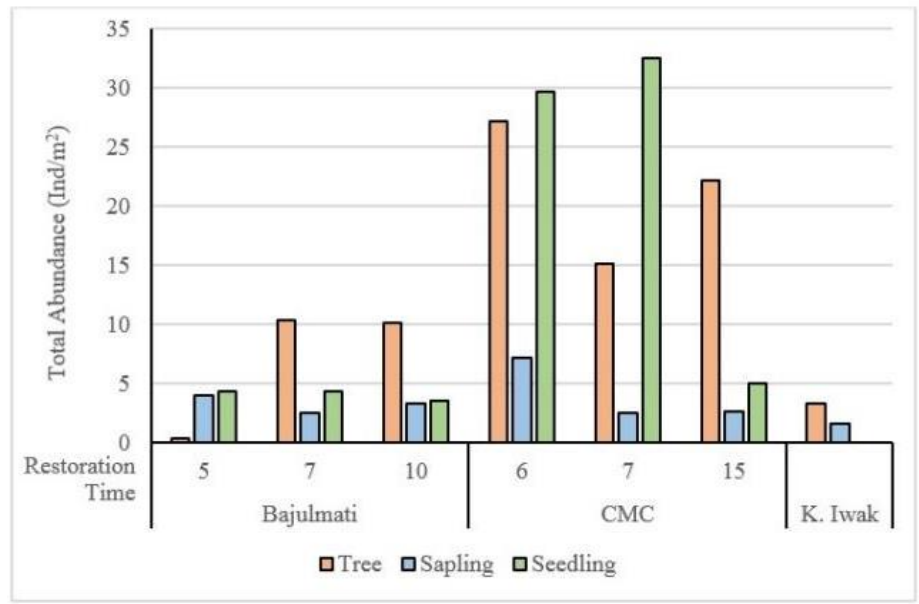

Figure 1. Total Abundance of Mangrove Vegetations

The highest total abundance value is at CMC. It shows that the mangrove rehabilitation program in the CMC was very structured and better than in Bajulmati. Whereas the famous Iwak has the lowest abundance of all locations. That is because the restoration program has not been carried out at that location, and when data collection occurred there was severe damage to the condition of the mangrove ecosystem due to illegal logging and land burning by irresponsible individuals.

The total abundance of mangrove vegetation at all three stations in Bajulmati and Kondang Iwak Beach showed the condition of mangrove ecosystems in a rare category with a small cover or less than $5 \%$ based on BB scores (table 1). The small cover was caused by a large number of mangrove trees felling to be used as firewood and building materials by local residents. In addition, floods in the area of stations 2 and 3 often occur, causing stunt and seedling growth to be hampered. Station 3 in CMC was an estuary where the water trapped can not flow into the sea and it surrounded by plantations owned by citizens, including corn, cassava, beans, and bananas plantations.

The high total abundance indicated that there were a number of individuals covering $25-50 \%$ of the area in station 1 and 2 , while the lowest percentage of land cover at station 3 was less than 5\% (table 1). The composition of mangrove trees in Station 3 was quite tight, but in the category of saplings and seedlings were very little found so that although there were many trees, the percentage of land cover was small. 
Table 1. Percentage of Land Cover Based on Braun-Blanquet (BB) Score

Location Restoration Time (year) BB Scale Land Cover (\%)

\begin{tabular}{cccc}
\hline K. Iwak & & 0.1 & $<5$ \\
Bajulmati & 5 & 0.1 & $<5$ \\
& 7 & 0.5 & $<5$ \\
\multirow{2}{*}{ CMC } & 10 & 0.5 & $<5$ \\
& 6 & 3 & 50 \\
& 7 & 2 & 25 \\
& 15 & 1 & $<5$ \\
\hline
\end{tabular}

\section{B. Analysis of Water Quality}

Water quality parameters were reviewed for pollution levels based on seawater quality standards according to MENLH No. 51 of 2004 concerning Sea Water Quality Standards for marine biota. Criteria for seawater quality standard parameters based on MENLH No. 51 of 2004 for turbidity must not be more than 5 NTU, the temperature of mangrove ecosystems ranges from 28 32 , values between $7-8.5$ for $\mathrm{pH}$, the percentage of salinity for mangrove ecosystems is maximum $34 \%$, the minimum concentration of $5 \mathrm{mg} / \mathrm{L}$ for DO and maximum $20 \mathrm{mg} / \mathrm{L}$ for BOD and not more than $0.015 \mathrm{mg} / \mathrm{L}$ for orthophosphate and $0.008 \mathrm{mg} / \mathrm{L}$ for nitrate (Table 2).

The forty-two plots showed a temperature range between 23 to $38{ }^{\circ} \mathrm{C}$, where Bajulmati has an average temperature of $\pm 27{ }^{\circ} \mathrm{C}$, while in $\mathrm{CMC}$ at $\pm 29.8{ }^{\circ} \mathrm{C}$ and Kondang Iwak averages $\pm 26.8 \mathrm{C}$ (table 3). Temperature conditions in accordance with the criteria marine water quality standard for marine biota only at the CMC with the range of $28-32{ }^{\circ} \mathrm{C}$ for the mangrove conservation area, while the other two locations do not match the criteria of marine water quality standards for marine biota. That's because the sampling time was done in the morning when the temperature conditions are down and the low intensity of sunlight.

Table 2. Sea Water Quality Criteria for Marine Biota (MENLH No. 51 of 2004)

\begin{tabular}{lll}
\hline Parameter & Unit & Standart \\
\hline $\begin{array}{l}\text { Physics: } \\
\text { Turbidity }\end{array}$ & NTU & $<5$ \\
Temperature & ${ }^{0} \mathrm{C}$ & Mangrove: $28-32$ \\
Chemistry: & & \\
pH & - & $7-8,5$ \\
Salinity & $\%$ & Mangrove: s/d 34 \\
DO & ppm & $>5$ \\
BOD & ppm & 20 \\
Phosphate (PO4-P) & ppm & 0,015 \\
Nitrate (NO3-N) & ppm & 0,008 \\
\hline
\end{tabular}

Turbidity at all three locations showed values between 3.45 385 NTU. Turbidity in Bajulmati and CMC ranged on average 19.56 and 385.24 NTU. This condition was not in accordance with the seawater quality standard for marine biota with a value of $<5$ NTU, while the turbidity in Kondang Iwak is 3.45 NTU (table 3), which means that the turbidity in Kondang Iwak is in a suitable condition for marine biota based on MENLH No. 51 of 2004 for marine biota.
The high turbidity value in Bajulmati caused by sandy mud substrate is the result of a mixture of the Bajulmati watershed which empties into Ungapan Beach. That causes very high turbidity and sedimentation which can kill the growth of marine biota in the surrounding area. In addition, the results from the disposal of shrimp pond waste and oil spills from ships used by tourists for river banking also contributed. Turbidity at the CMC location was very high especially at Station 2 , it was caused by the substrate of mud and sand resulting from frequent flash floods that hit the area of Station 2.

The degree of acidity $(\mathrm{pH})$ of water at the three locations showed relatively normal results because it was still in the range of $7-8.5$ in the seawater quality standard for marine biota. The $\mathrm{pH}$ of Bajulmati showed an average value of 7.5 while the average CMC was 7.6 and Kondang Iwak has an average value of 8.2 (table 3). According to Millero [10], seawater has the ability as a buffer in maintaining $\mathrm{pH}$ to always be alkaline, so that its value is relatively stable and this system is known as the seawater carbonate system. High or low pH of the water was influenced by the content of compounds in the water. Factors that affect the $\mathrm{pH}$ of the water are the rest of the feed and sediment that settles to the bottom of the water.

Salinity levels in Bajulmati showed a range between 11.8 $15.7 \%$ indicated that this location was in a suitable condition for marine biota while in CMC was 19.2 - 28.2\% (stations 2 and 3) but for station 1 showed the value unsuitable for marine biota which was $37.7 \%$ based on MENLH No.51 of 2004 concerning water quality standards for marine biota with a maximum value of $34 \%$. The salinity condition of $0 \%$ in Kondang Iwak was caused by the condition of the waters located in the trapped water that is far from the sea (it called Kondang) (table 3). Salinity describes the total concentration of ions contained in a body of water with the main constituent ions such as sodium, potassium, magnesium, and chloride [10]. Salinity will vary vertically and horizontally depending on freshwater, rainwater, and evaporation inputs. Salinity has an important role in the life of marine organisms and the solubility of gases in seawater. Salinity is also one of the environmental factors that influence the existence of mangrove species.

Dissolved oxygen (DO) showed that the highest average was at station 3 in Bajulmati with a value of $5.32 \mathrm{ppm}$, followed by Kondang Iwak $4.075 \mathrm{ppm}$ then $\mathrm{CMC}$ (stations 2, 3 and 1) respectively $3.6 \mathrm{ppm}, 3.2 \mathrm{mg} \mathrm{ppm}$, and $3.1 \mathrm{ppm}$, the lowest DO in Bajulmati (station 2 and 1) respectively $2.7 \mathrm{ppm}$ and $2.4 \mathrm{ppm}$ (table 3). DO values other than at Station 3 Bajulmati were classified as low and not in accordance with seawater quality standards based on MENLH No. 51 of 2004, which is not less or a minimum of $5 \mathrm{ppm}$. A low range on DO value allegedly caused by the sampling time which pertained morning.

The DO value was expected to increase with increasing sunlight intensity and the photosynthesis process. DO levels according to Effendi [11] fluctuate daily (diurnal) and also seasonal, depending on the mixing and movement (turbulence) of water masses, photosynthetic activity, respiration, and effluent into the water bodies. DO is a gas that is needed by all living things, both on land and water. The water body can be said as good and has a low level of pollution if it has DO levels greater than 5 ppm [12].

BOD concentrations in the three locations averaged between 3.3 - 9.29 ppm (table 3). The BOD value was still below the standard 
according to MENLH No. 51 of 2004 concerning seawater quality standards for marine biota, which is $20 \mathrm{ppm}$. BOD value is known to indicate the level of pollution in the waters [12]. The range of BOD values in the three locations showed that the waters were included in the low pollution level. Low pollution levels have a BOD range of 0 to $10 \mathrm{ppm}$ [12].

Nitrate is one of the three main forms of nitrogen compounds in seawater. Nitrate is often used as an indicator of water fertility. Nitrate levels in the three locations ranged from 0.02 to $0.11 \mathrm{ppm}$ (table 3), all of which exceeded the quality standard of MENLH No. 51 of 2004, which is 0.008 ppm. The high concentration of nitrate in seawater was influenced by its solubility [13].

Table 3. Water Parameters Result

\begin{tabular}{lrrrrrrr}
\hline & \multicolumn{3}{c}{ Bajulmati } & \multicolumn{3}{c}{ CMC } & \begin{tabular}{c} 
K. \\
\cline { 2 - 6 }
\end{tabular} \\
\cline { 2 - 6 } & \multicolumn{1}{c}{5} & \multicolumn{1}{c}{7} & \multicolumn{1}{c}{10} & \multicolumn{1}{c}{6} & \multicolumn{1}{c}{7} & \multicolumn{1}{c}{15} & \\
\hline Twak \\
pH & 29 & 27.5 & 24.5 & 34.7 & 26.2 & 28.8 & 26.8 \\
DO & 8.06 & 7.18 & 7.2 & 7.7 & 7.8 & 7.4 & 8.18 \\
Salinity & 11.83 & 14.7 & 15.7 & 37.7 & 19.17 & 28.17 & 0 \\
Turb & 10.58 & 35.63 & 12.45 & 257.2 & 492.2 & 406.3 & 3.45 \\
BOD & 8.27 & 5.79 & 3.5 & 8.75 & 8.02 & 9.29 & 3.3 \\
Nitrate & 0.1 & 0.08 & 0.11 & 0.05 & 0.02 & 0.05 & 0.09 \\
PO4 & 0.2 & 0.14 & 0.18 & 0.07 & 0.07 & 0.02 & 0.23 \\
\hline
\end{tabular}

The results of testing orthophosphate levels in water samples at the three study sites showed values between $0.07-0.23 \mathrm{ppm}$ (table 3). This concentration has exceeded the seawater quality standard for biota according to MENLH No.51 of 2004, which is $0.015 \mathrm{ppm}$. High and low levels of phosphorus in the waters were influenced by the input of organic matter carried by the river flow. On average all stations have low salinity values and tend to be brackish [14].

\section{Analysis of Macroinvertebrates}

The results of macroinvertebrate identification which were divided into two major groups namely gastropods and crabs were found 20 species of gastropods and 9 species of crabs (table 4). Species diversity (H') is characteristic of the level of communitybased on its biological organization. H' can be used to express the structure of a community, it can also be used to measure community stability, namely the ability of a community to keep itself stable even though there were disturbances to each of its components [15]. H' from gastropods at station $3 \mathrm{CMC}$, Kondang Iwak, and station 2 Bajulmati were classified low based on the diversity index benchmark values, respectively $0.2,0.4$, and 0.9 (less than 1). The highest H' value was found in Station 3 Bajulmati, which is 2.2. This value was also classified as a medium based on the benchmark index of diversity (between 1 3) (fig. 2).

The more number of species with the same or a close number of individuals, the higher level of heterogeneity. The highest $\mathrm{H}^{\prime}$ value of crabs was at station $1 \mathrm{CMC}$ with 2.4 (fig. 2). The value was still classified as moderate based on the diversity index benchmark (between 1-3). In line with the dominance and $\mathrm{E}$ values, the crabs at the three Bajulmati stations and Kondang Iwak were zero ( 0 ) because only one type of crab was found in the area.

Table 4. Distributions of Gastropods and Crabs

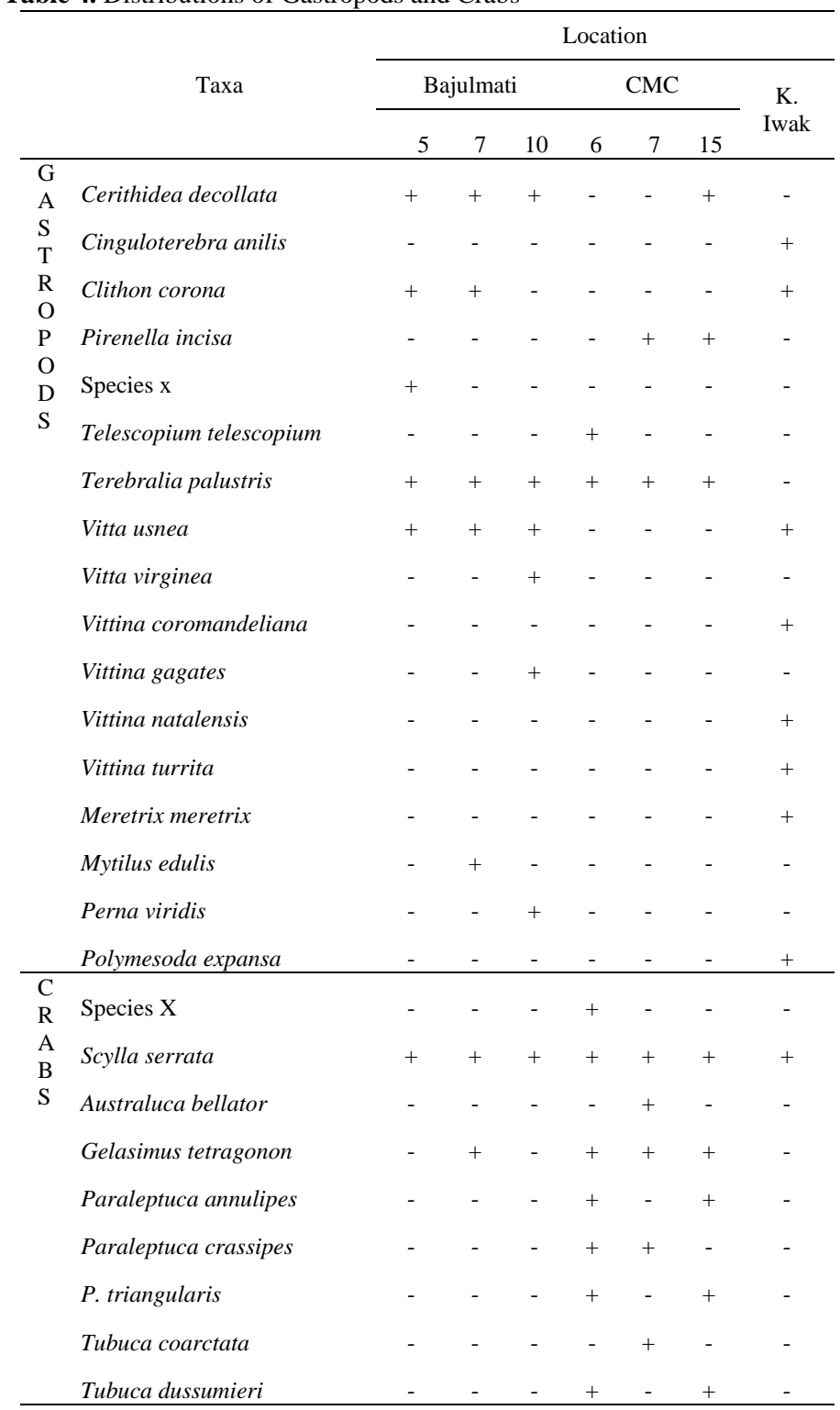

Factors that influence the presence and selection of aquatic fauna living areas were environmental factors that comprised the habitat. Each component of these elements has different effects on each type or group of types. Environmental factors have a beneficial or detrimental impact on the presence of aquatic fauna. Each habitat type has a combination or set of factors that are different from other habitat types [16]. This means that water conditions, habitats, or ecosystems changes that affect the waters will also affect the community structure and function of aquatic fauna. The Importance Value Index (IVI) showed the importance of a species and its role in the community, where the significance value was obtained from the sum of Relative Abundance (RA) and Relative Frequency (RF). In this case, the total amount of RA and RF must be $100 \%$, so the total amount of IVI is $200 \%$. The existence of a dominant species at the study site becomes an 
indicator that the community is an appropriate habitat and supports its growth.

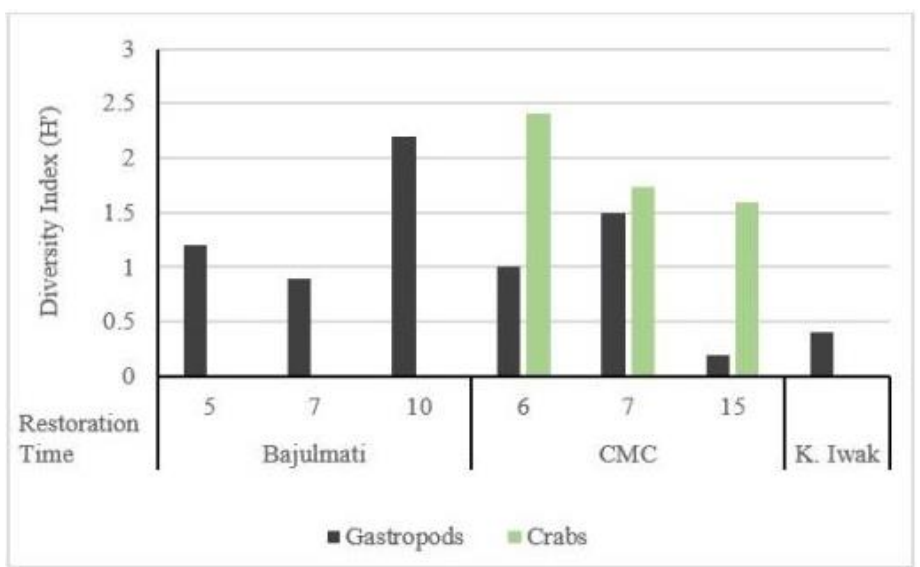

Figure 2. The Diversity Index of Gastropods and Crabs

The highest IVI of gastropods was occupied by mangrove snail species, Terebralia palustris which were found in almost all locations except in Kondang Iwak (fig. 3). According to Frattini, et al [17], T. palustris is a gastropods that has a shell composed of calcium carbonate which has the ability to life in tidal conditions. T. palustris tends to choose a place to life only on the surface of sediments which sand and muddy substrate [18]. Turbidity in the $\mathrm{CMC}$ location has the highest value compared to the other two locations, it reinforced the notion that the high IVI value of $\mathrm{T}$. palustris at $\mathrm{CMC}$ was due to the high turbidity value.

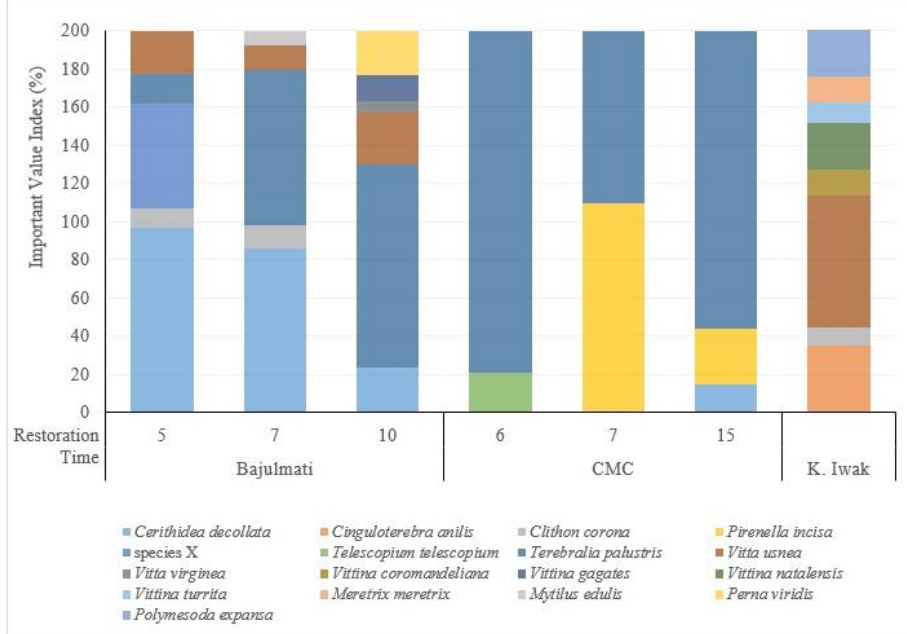

Figure 3. Important Value Index of Gastropods

The highest IVI value of crabs was from the mangrove crabs species, Scylla serrata that found in all study sites (fig.4). Mangrove crab or mud crab or sometimes called black crab is one of fisheries resources that live in the coastal area and in particular in the mangrove area. Ecological conditions play an important role in the sexual maturity of mud crab through the amount of available food and the environmental temperature. Reduction in mangrove swamp area may perturb the food chain in the mangrove swamp affecting crab sizes at sexual maturity while the spawning [19]. Almost all the types of crabs were in the form of the first crab stage (juvenile). Juvenil inhabits the upper intertidal area (sometimes hiding under rocks or areas between pneumatophores of Avicennia marina near the mangrove fringe) during low tide and to avoid larger aquatic predators [20]. The juvenile according to Baylon [21] can not survive at temperatures below $20^{\circ} \mathrm{C}$, while Nurdiani [22] stated that the best survival rates were reached at 28 and 29 ${ }^{0} \mathrm{C}$, respectively and with minimum salinities of $25-30$, that is the reason juvenile of Scylla serrata was found in all study sites because the average of temperature conditions above $23{ }^{\circ} \mathrm{C}$ and were in high salinity.

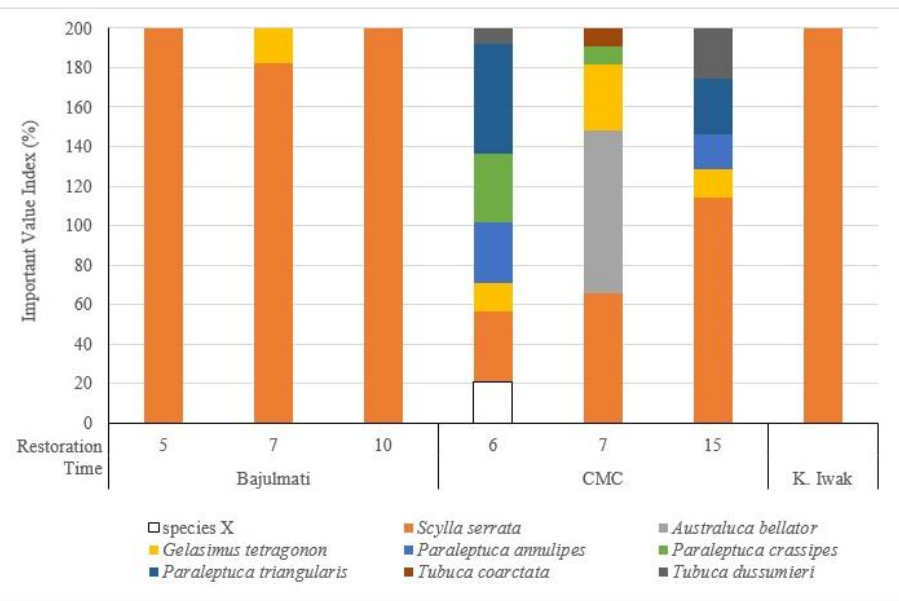

Figure 4. Important Value Index of Crabs

More recently, characteristics of the faunal community in mangrove forests areas are being included in rehabilitation assessments. Due to their conspicuousness and importance in ecosystem function, mollusks, mudskippers, and crabs are commonly used as indicators [23]. The study of Irma, et al [24] in Sumatra, Indonesia concluded that gastropod abundance positively correlates with the age of rehabilitated mangroves. Although mudskippers have not been used specifically to assess mangrove rehabilitation, they have been suggested as potential bioindicators for the health of mangrove ecosystems.

\section{Principal Component Analyisis (PCA)}

PCA is a descriptive statistical method that aims to display data in graphical form and maximum information contained in a data matrix [25]. The PCA have a component that were called Biplot. Biplot serves to determine the grouping and the parameters of identifiers based on the zone and observation period of this analysis is used to observe the similarities and linear correlations between objects and environmental parameters observed [26]. PCA analysis using PAST3 (Paleontological Statistics) software. The results of the PCA analysis show the research parameters or variables that play an important role, especially those that affect the existence of aquatic fauna [27].

Based on PCA analysis, it was found that the dominant physicochemical parameters affecting mangrove vegetation were salinity, nitrate and orthophosphate, with a total variance of the two components of $81.782 \%$ (fig. 5). Mangrove vegetation and salinity were positively correlated only at CMC. That is because the sea water supply is greater than the other two locations which were mostly supplied with brackish water. It shows that restoration program in CMC better than Bajulmati did. In addition, as explained above that the location of Bajulmati often floods, 
causing mangrove saplings that have just been planted damaged by the flood currents. The longest restoration year actually shows the results of the structure of mangrove vegetation which tends to be lower than the newly restored. That's because the high density at the level of saplings and seedlings that overflows the study plot, on the contrary, trees dominate over the longest year restoration area.

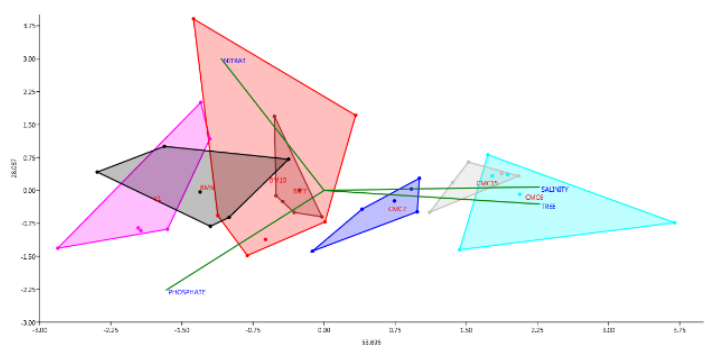

Figure 5. Principal Component Analysis of Mangrove Vegetation

Abiotic parameters that affect the gastropods diversity were salinity, orthophosphate and BOD, with a total variance of the two components of $77.425 \%$. Orthophosphate and gastropods were positively correlated in Bajulmati and Kondang Iwak (fig. 6). According to Kurniawaty, et al [28], gastropod groups living in mangrove ecosystem areas tend to choose habitat criteria that have open land, fine mud, large enough puddles, and have a high availability of organic matter. It was accordance with the conditions of organic material in Bajulmati and Kondang Iwak which tend to be higher than $\mathrm{CMC}$, which causes a high diversity of gastropods.

The diversity of crabs based on the results of the PCA analysis was influenced by salinity, BOD and orthophosphate, with a total variance of the two components of $78,069 \%$. BOD and salinity levels were positively correlated with crabs diversity in CMC (fig. 5). According to Unthari, et al [29], the range of salinity that can be tolerated by mangrove crabs is $10 \%-33 \%$, but also from several studies that mangrove crabs can still survive for salinity that is more than $33 \%$. The high BOD value and diversity of crabs in CMC illustrates that at these locations crabs carry out many metabolic activities so that the results of these activities can affect the BOD levels of waters.

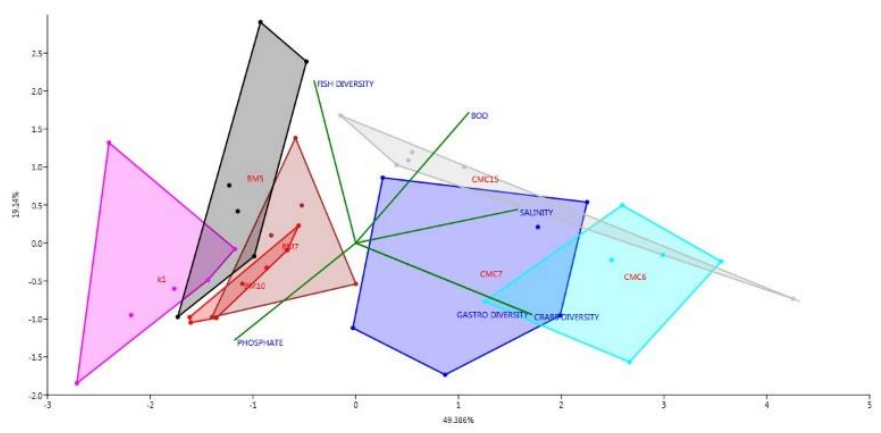

Figure 5. Principal Component Analysis of Macroinvertebrates

\section{E. Recommendation Strategies Based on Evaluating The Success of Restoration Program}

There are some strategies that can be recommended for the sustainability of the restoration program based on the evaluation results of the success of the restoration program. First, the adoption of a policy to stop the conversion of conservation areas to other uses. In this case, the official authorized to do so by giving the sense that in addition to the role of mangrove ecosystems vital for life, also has a high economic if managed properly. The second strategic step, is to improve the governance of mangrove conservation areas, National Parks, Nature Reserves and wildlife reserves. This step is very much needed for Bajulmati location because CMC has been designated as a conservation area and protected by law. With the existence of mangrove conservation areas that are maintained then at least there is a mangrove area that really functions as a protected area, which mangrove ecosystem is really maintained.

The third strategic step, is that mangrove protection conservation programs must be community-based, because so far many conservation or rehabilitation programs have failed because they do not involve the surrounding community. CMC is located quite far from residential areas, so the conservation program will not interfere with the activities of the surrounding community. Compared with Bajulmati are adjacent to the settlement, so that the role of the community will greatly help the success of the conservation program.

$\mathrm{CMC}$ is one of the most developed mangrove ecotourism areas. Most of the ecotourism activities at CMC were only centered on mangrove conservation. Because as well known, mangrove ecosystems not only contain these plants, but also other biotic components that associated with mangrove. Same as in Bajulmati, ecotourism activities in Bajulmati were only planting mangrove seedlings. The last recommendation strategy is making an ecotourism in the conservation area that preserves aspects of local wisdom and involving local community while maintaining ecosystem health. Several ways to develop the potential of ecotourism there were opening fishing, birdwatching, increasing the participation of relevant agencies in improving facilities and infrastructure, community education level, access to the location, and the zoning of the area.

\section{CONCLUSION}

The success of mangrove restoration in terms of the assessment of provisioning services showed sufficient results to provide a variety of benefits both for the ecosystem and surrounding communities. The products from the restoration program were in the form of wood production and the presence of various types of aquatic fauna. The land cover in all three locations showed a moderate percentage (between 5 - 50\%). Gastropods found in all locations (except Kondang Iwak) were Terebralia palustris (mangrove snails), while crab species found in all locations were Scylla serrata (mangrove crabs) and fish that have the highest IVI, was Periophthalmus sp. Both products can be used as an ecological approach to protect coastal areas from degradation, one of which made the area an ecotourism location.

\section{ACKNOWLEDGMENT}

The author would like to thank the South Malang POKMASWAS institution and related agencies that have provided assistance for the process of data collection in the research field. 


\section{REFERENCES}

[1] Giri, C., E. Ochieng., L. L. Tieszen., Z. Zhu., A. Singh., T. Loveland., J. Masek., N. Duke. 2011. Status and Distribution of Mangrove Forests of The World Using Earth Observation Satellite Data. Global Ecology Biogeography. 20: 154-159.

[2] Brown, E. D and B. K, Williams. 2016. Ecological Integrity Assessment As a Metric Of Biodiversity: Are We Measuring What We Say We Are? Biodiversity and Conservation. 25. 6: 1011-1035.

[3] Khavari, A. A and B. J. Richardson. 2019. Ecological Restoration Law: Concepts and Case Studies. Routledge. New York.

[4] Zambrano, A. M. A., E. N. Broadbent., W. H. Durham. 2010. Social and Environmental Effect of Ecotourism in The Osa Peninsula of Costa Rica: The Lapa Rios Case. Journal of Ecotourism. 9. 1: 62 - 83.

[5] Merryanti, D. P. 2016. Strategi Pengembangan Kawasan Ekowisata Bahari Berbasis Restorasi Di Pulau Pramuka Taman Nasional Kepulauan Seribu. [Undergraduate Thesis]. Brawijaya University.

[6] Harahab, N., Setiawan. 2017. Suitability Index of Mangrove Ecotourism in Malang Regency. Journal of Economic and Social of Fisheries and Marine. 4. 2: $153-165$.

[7] Ren, Y., Y. Lu., B. Fu. 2016. Quantifying The Impacts of Grassland Restoration on Biodiversity and Ecosystem Services in China: A MetaAnalysis. Ecology Engineering. 95: 542-550.

[8] English, S., C. Wilkinson., V. Baker. 1994. Survey Manual For Tropical Marine Resources. ASEANAustralia Marine Science Project: Living Coastal Resources, Australian Institute of Marine Science. Townsvile (AUS).

[9] Dombois, M., H, Ellenberg. 1974. Aim and Methods of Vegetation Ecology. Jhon Wiley \& Sons. New York.

[10] Millero F. J., M. L. Sohn. 1992. Chemical Oceanography. CRC Press. Boca Raton.

[11] Effendi, H. 2003. Telaah Kualitas Air: Bagi Pengelolaan Sumberdaya dan Lingkungan Perairan. Kanisius. Yogyakarta.

[12] Salmin. 2005. Oksigen Terlarut (DO) dan Kebutuhan Oksigen Biologi (BOD) sebagai Salah Satu Indikator Untuk Menentukan Kualitas Perairan. Jurnal Oseana, 30: 21-26.

[13] Indrayani, E., H. Kamiso., S. Nitimulyo., Hadisusanto., Rustadi. 2015. Analisis Kandungan Nitrogen, Fosfor dan Karbon Organik di Danau SentaniPapua. J. Manusia dan Lingkungan. 22. 2: 217-225.

[14] Rizal, A. C., Y. N. Ihsan., E. Afrianto., L. P. S. Yuliadi. 2017. Pendekatan Status Nutrien pada Sedimen untuk Mengukur Struktur Komunitas Makrozoobentos di Wilayah Muara Sungai dan Pesisir Pantai Rancabuaya, Kabupaten Garut. Jurnal Perikanan dan Kelautan. 8. 2: 7 - 16.

[15] Krebs, C.J. 1989. Ecological Methodology. Harper \& Row Inc. Publisher. New York.

[16] Su, Q. 2016. Analyzing Fractal Property of Species Abundance Distribution and Diversity Indexes. Journal of Theoretical Biology. 392: 107-112.

[17] Frattini, S., S. Cannicci., M. Vannini. 2001. Feeding Clusters and Olfaction in The Mangrove Snail Terebralia palustris (Linnaeus) (Potamididae: Gastropoda). Journal of Experimental Marine Biology and Ecology. 261: 173 $-183$.

[18] Frattini, S., V. Vigiani., M. Vannini., S. Cannicci. 2004. Terebralia palustris (Gastropoda; Potamididae) in A Kenyan Mangal: Size Structure, Distribution and Impact on The Consumption of The Leaf Litter. Marine Biology. 144: $1173-1182$
[19] Tetelpta, J. M. S., A. S. Khouw, Y. Natan, O. T. S. Ongkers. 2017. Some Biological Aspects of Mud Crab Scylla serrata (Forskal) Fisheries at Pelita Jaya Bay, Western Seram Regency, Indonesia. International Journal of Fisheries and Aquatic Studies. 5. 5: 272 - 277.

[20] Mirera, D. O. 2014. Capture-Based Mud Crab (Scylla serrata) Aquaculture and Artisanal Fishery in East Africa-Practical and Ecological Perspectives. [PhD thesis]. Linnaeus University, Kalmar, Sweden.

[21] Baylon, J. C., 2010. Effects of Salinity and Temperature on Survival and Development of Larvae and Juveniles of The Mud Crab, Scylla serrata (Crustacea: Decapoda: Portunidae). Journal of the World Aquaculture Society. 41: 858-873.

[22] Nurdiani, R., C. Zeng. 2007. Effects of Temperature and Salinity on The survival and Development of Mud Crab, Scylla serrata (Forsskal), Larvae. Aquaculture Research. 38: 1529-1538.

[23] Thornton, S. R., R. W. Johnstone. 2015. Mangrove Rehabilitation in High Erosion Areas: Assessment Using Bioindicators. Estuarine, Coastal and Shelf Science. 165: 176 - 184.

[24] Irma, D., K. Sofyatuddin. 2012. Diversity of Gastropods and Bivalves in Mangrove Ecosystem Rehabilitation Areas in Aceh Besar and Banda Aceh District, Indonesia. AACL Bioflux. 5: 55 - 59.

[25] Rustam, A., F. Y. Prabawa. 2015. Kualitas Perairan di Pantai Punai dan Pantai Tambak Kabupaten Belitung Timur. Jurnal Segara. 11. 1: 75 - 84.

[26] Tambaru, R. 2008. Dinamika Komunitas Fitoplankton dalam Kaitannya dengan Produktivitas Perairan di Perairan Pesisir Maros Sulawesi Selatan. [Dissertation]. Postraduate Program of Bogor Agricultural Institute.

[27] Fachri, F.R., Afdal., A. Sartimbul., N. Hidayati. 2015. Fluks CO2 di Perairan Pesisir Timur Perairan Pulau Bintan. Provinsi Kepulauan Riau. Jurnal Segara. 11. 1: 57-66.

[28] Kurniawaty, A., D. G. Bengen., H. Madduppa. 2014. Characteristics of Telescopium telescopium on Mangrove Ecosystem at The Segara Anakan Lagoon, Cilacap District, Central Java. Bonorowo Wetlands. 4. 2: 71 - 81.

[29] Unthari, D. T., A. I. S. Purwiyanto., A. Agussalim. 2018. Relation of Mangrove Density and Mud Crab (Scylla sp) Abundance With The Use of Bubu Lipat As Fishing Gear in Bungin River, Banyuasin Regency, South Sumatera Province. Maspari Journal. 10. 1: 41 - 50.

\section{AUTHORS}

First Author - Ayu Maharani Siswandari, Magister Program of Bioloy, University of Brawijaya, Email: windaaa049@gmail.com. Second Author - Catur Retnaningdyah, Doctoral of Aquatic Ecosystem, University of Brawijaya, Email: caturretnaningdyah@gmail.com

Third Author - Luchman Hakim, Professor of Management Conservation Areas, University of Brawijaya, Email: luchman@ub.ac.id

Correspondence Author - Ayu Maharani Siswandari, Email: windaaa049@gmail.com +62859183951021. 